\title{
Pesticide exposure and risk of mild cognitive dysfunction.
}

Citation for published version (APA):

Bosma, J. H. A., van Boxtel, M. P. J., Ponds, R., Houx, P. J., \& Jolles, J. (2000). Pesticide exposure and risk of mild cognitive dysfunction. Lancet, 356, 356-356. https://doi.org/10.1016/S0140-6736(00)02685-4

Document status and date:

Published: 01/01/2000

DOI:

10.1016/S0140-6736(00)02685-4

Document Version:

Publisher's PDF, also known as Version of record

\section{Please check the document version of this publication:}

- A submitted manuscript is the version of the article upon submission and before peer-review. There can be important differences between the submitted version and the official published version of record.

People interested in the research are advised to contact the author for the final version of the publication, or visit the DOI to the publisher's website.

- The final author version and the galley proof are versions of the publication after peer review.

- The final published version features the final layout of the paper including the volume, issue and page numbers.

Link to publication

\footnotetext{
General rights rights.

- You may freely distribute the URL identifying the publication in the public portal. please follow below link for the End User Agreement:

www.umlib.nl/taverne-license

Take down policy

If you believe that this document breaches copyright please contact us at:

repository@maastrichtuniversity.nl

providing details and we will investigate your claim.
}

Copyright and moral rights for the publications made accessible in the public portal are retained by the authors and/or other copyright owners and it is a condition of accessing publications that users recognise and abide by the legal requirements associated with these

- Users may download and print one copy of any publication from the public portal for the purpose of private study or research.

- You may not further distribute the material or use it for any profit-making activity or commercial gain

If the publication is distributed under the terms of Article $25 \mathrm{fa}$ of the Dutch Copyright Act, indicated by the "Taverne" license above, 


\section{Pesticide exposure and risk of mild cognitive dysfunction}

\author{
H Bosma, M P J van Boxtel, R W H M Ponds, P J Houx, J Jolles
}

Little is known about the adverse effects of substances, such as pesticides and metals, on the development of mild cognitive dysfunction (MCD). Cross-sectional and prospective data from the Maastricht Aging Study were used to find out the potential neurotoxicity of particular substances. Exposure to pesticides, for example by arable farmers and gardeners, was associated with increased risks of MCD. Exposure to metals and organic solvents was not associated with MCD. Our findings might reflect subtle changes in brain function among people exposed to pesticides.

Few population-based prospective studies have been done to examine the neurotoxicity of exposure to organic solvents, metals, pesticides, and other substances. ${ }^{1}$ Furthermore, little is known about the possibility of subtle changes in brain function resulting from such exposure. The development of cognitive dysfunction in a non-demented population may be indicative of such changes. ${ }^{2}$ Our aim was to find out whether people exposed to particular substances have higher risks of mild cognitive dysfunction (MCD) compared with unexposed people.

We used data from the Maastricht Aging Study (MAAS), ${ }^{3}$ which is a prospective cohort study of cognitive ageing in southern Netherlands. After the 1993-95 baseline examination of 1069 non-demented people aged 50-80 years (541 men, 528 women), there was a 3-year follow-up examination (1996-98) of 838 people. Eight individuals who had developed dementia were excluded. In the baseline questionnaire, all 830 individuals were asked whether they had been frequently exposed to organic solvents (56 [7-1\%] reported exposure), metals (40 [5.1\%]), pesticides (17 $[2 \cdot 2 \%])$, and other chemical substances $(40[5 \cdot 1 \%])$ at work, while carrying out a hobby, or elsewhere. Self-reported exposure data were available for 791 people with follow-up data.

In addition, a job-related exposure measure was created. 3127 people, including those who were not invited for neuropsychological testing or follow-up according to the MAAS protocol, ${ }^{3}$ provided self-reported exposure data (similar proportions reported exposure). By these extended data, the percentage of people reporting exposure for each three-digit job-title code (Statistics Netherlands, Heerlen, Netherlands) was calculated. To increase reliability of this score and to reduce reporting bias, the procedure was restricted to jobs with ten or more respondents. By matching the score to the individual, a high score indicated that the individual had or has a job in which a high percentage of people reported exposure. The score may be interpreted as the individual's probability of job-related exposure. Basic statistics for these scores were as follows: organic solvents, mean 8 (SD 11), range 0-56; metals, 5 (10), 0-75; pesticides, 1 (5), 0-67; other chemicals, 5 (10), 0-69. Job-related exposure data were available for 629 of 791 people with follow-up data.
MCD was defined by at least two scores in the lowest decile of the following five neuropsychological tests: Stroop colour word test, verbal learning test (immediate and delayed recall), letter digit coding test, and word fluency test. Similar tests have been used to measure postoperative cognitive dysfunction. ${ }^{4}$ This measure of MCD is indicative of cognitive impairment without dementia. ${ }^{2}$ Similar cut-off scores were used at baseline and follow-up (prevalence $12 \%$, cumulative incidence $6 \%$ ).

Of the 17 people who reported pesticide exposure, six (35\%) had MCD at baseline, whereas only $85(11 \%)$ of 774 individuals in the unexposed group had MCD. The risk of MCD for exposed individuals was nearly five times higher than for unexposed individuals (table). Similarly, individuals in jobs with many people who reported exposure to pesticides (job-related measure) had increased risks of MCD. Each ten percentage point increase on the job-related measure corresponded to a $47 \%$ higher risk of MCD. During followup, exposure to pesticides was also related to incident MCD. Two $(18 \%)$ of 11 people reporting pesticide exposure developed MCD during follow-up, compared with only 37 $(5 \%)$ of 689 people in the unexposed group (table). Arable farmers and gardeners had the highest probability of pesticide exposure $(>50 \%)$. Exposure to organic solvents, metals, and other chemicals was not associated with MCD. Substances had no interactive effects (multiplicative interaction terms were not significant; data not shown).

Exposure to pesticides was consistently associated with the separate neuropsychological test results and the longitudinal changes thereof (data not shown). Results did not differ significantly or consistently between currently and previously employed (eg, retired) people. This may indicate long-term adverse effects of pesticide exposure. Effect modification or confounding by alcohol consumption, smoking, drugs, family history of dementia, head trauma, relevant diseases (eg, cardiovascular diseases), and mental workload did not substantially affect the findings. Exposure was not associated with the $22 \%$ attrition during follow-up. However, because of the small numbers, the results should be interpreted cautiously.

Our findings suggest that people who are frequently exposed to pesticides, such as arable farmers and gardeners, may have a higher risk of developing MCD. In this nondemented population, this increase in risk might reflect subtle changes in brain function among exposed people. These findings should be replicated in other studies with larger numbers of exposed people and detailed information on severity, frequency, and duration of exposure to specific neurotoxic compounds.

This study was done in close collaboration with the Registration Network Family Practices and related general practitioners. We thank

Anita Hendriks, Carlein Karimoen, Mieke Kessel, Riet Landeweerd, Astrid Quist, and Nico Rozendaal for assistance in medical and neuropsychological testing and database construction.

This work was supported in part by a grant from the Dutch Ministries of Education and Health and Welfare, via the Steering Committee for Gerontological Research (NESTOR), and is part of MAAS.

1 Hartman DE. Neuropsychological toxicology. Identification and

\begin{tabular}{|c|c|c|c|c|c|}
\hline & \multirow[t]{2}{*}{ Number with MCD/total } & \multicolumn{4}{|c|}{ Adjusted* odds ratios (95\% Cl) } \\
\hline & & Organic solvents & Metals & Pesticides & Other chemicals \\
\hline \multicolumn{6}{|c|}{ Cross-sectional } \\
\hline Self-reported & $91 / 791(11.5 \%)$ & $1.52(0.63-3.66)$ & $0.65(0.18-2.35)$ & $4.94(1.53-16 \cdot 1)$ & $0.45(0.10-2.03$ \\
\hline Job-related $\dagger$ & $67 / 629(10 \cdot 6 \%)$ & $1.10(0.85-1.43)$ & $1.11(0.89-1.38)$ & $1.47(1.03-2 \cdot 10)$ & $0.87(0.62-1.23)$ \\
\hline \multicolumn{6}{|l|}{ Prospective } \\
\hline Self-reported & $39 / 700$ (5.6\%) & $1.45(0.37-5.70)$ & $1.14(0.23-5.66)$ & $3.07(0.51-18.4)$ & $1.21(0.25-6.02)$ \\
\hline Job-related $\dagger$ & $36 / 561$ (6·4\%) & $1.17(0.81-1.67)$ & $0.95(0.64-1.42)$ & $2.02(1.27-3.20)$ & $1.00(0.67-1.50)$ \\
\hline
\end{tabular}

*Adjusted for age, sex, and education in cross-sectional analyses, and for age, sex, education, and length of follow-up in longitudinal analyses (patients with MCD at baseline were excluded from longitudinal analyses). †Odds ratios for job-related measure indicate an increase in odds of MCD according to a ten percentage point increase on this measure. Risk of MCD by self-reported and job-related exposure to potential neurotoxins 
assessment of human neurotoxic syndromes. New York: Pergamon Press, 1988.

2 Ritchie K, Touchon J. Mild cognitive impairment: conceptual basis and current nosological status. Lancet 2000; 355: 225-28.

3 Van Boxtel MPJ, Buntinx F, Houx PJ, Metsemakers JFM, Knottnerus A, Jolles J. The relation between morbidity and cognitive performance in a normal aging population. F Gerontol 1998; 53A: M147-54.

4 Moller JT, Cluitmans P, Rasmussen LS, et al. Long-term postoperative cognitive dysfunction in the elderly: ISPOCD1 study. Lancet 1998; 351: 857-61.

5 O'Malley M. Clinical evaluation of pesticide exposure and poisonings. Lancet 1997; 349: 1161-66.

Department of Psychiatry and Neuropsychology, Maastricht Brain and Behaviour Institute and European Graduate School of Neuroscience (EURON), Maastricht University, PO Box 616, 6200

MD Maastricht, Netherlands (H Bosma PhD, M P J van Boxtel PhD,

R W H M Ponds PhD, P J Houx PhD, Prof J Jolles PhD)

Correspondence to: $\mathrm{Dr} \mathrm{H}$ Bosma

(e-mail: h.bosma@np.unimaas.nl)

\section{Increased prevalence of renal disease in silica-exposed workers}

Sean Fenwick, John Main

We report an increased prevalence of renal disease, particularly glomerulonephritis, in Upper Weardale, UK. Silica exposure during fluorspar mining and processing is a likely cause.

In our hospital, we noted that a disproportionate number of patients with renal disease were fluorspar workers from a remote area of Upper Weardale. Fluorspar mining and processing was the major occupation there for most of the 20 th century. We tried to establish whether this apparent excess of renal disease was real and what might be the cause.

With the help of fluorspar miners and a local family physician we defined the area of Upper Weardale in which the fluorspar mines and their associated villages were based. This area-the mining area-was entirely within the family physician's practice and allowed a comparison with the rest of the area the practice covered (the non-mining area). A case of renal disease was defined as any patient with a renal disorder under the care of a nephrologist as an inpatient or outpatient when a link between fluorspar mining and renal disease was suggested. Cases of renal disease were identified from the clinical database of the hospital renal outpatient clinic that served this area, confirmed by crossreferencing with the family physician's records. The clinic's database was also used to compare the mining and nonmining areas. An occupational history was taken from all patients identified as having renal disease in these areas. Statistical analyses were done by $\chi^{2}$ test with Yates' correction. The results confirmed an excess of renal disease, especially glomerulonephritis, in the mining area (table 1). Details of occupation, silica exposure, and renal diagnosis are shown in table 2 . Of the six workers with long-term silica exposure, five had biopsy-proven glomerulonephritis and the sixth had signs and symptoms compatible with chronic glomerulonephritis.

\begin{tabular}{|c|c|c|c|}
\hline & Mining area & $\begin{array}{l}\text { Non-mining } \\
\text { area }\end{array}$ & Clinic area \\
\hline Population & 1645 & 5600 & 130000 \\
\hline Cases (per thousand) & $8(4.9)$ & $2(0.36)^{*}$ & $156(1 \cdot 2)$ \\
\hline Glomerulonephritis (per thousand) & $6(4 \cdot 25)$ & $1(0.18)^{*}$ & $47(0.36)$ \\
\hline Sex (male [n/total]) & $7 / 8$ & $0 / 2$ & $87 / 156$ \\
\hline $\begin{array}{l}\text { Renal replacement (prevalence per } \\
\text { million) }\end{array}$ & $2(1216)$ & $2(357)$ & $56(410)$ \\
\hline
\end{tabular}

${ }^{*} p<0.001$ for mining area compared with non-mining area.

Table 1: Renal disease in fluorspar mining and non-mining areas of Upper Weardale and local renal clinic

\begin{tabular}{|c|c|c|c|c|c|c|}
\hline Patient & Age & Sex & Occupation & $\begin{array}{l}\text { Silica } \\
\text { exposure } \\
\text { years }\end{array}$ & Diagnosis & Renal status \\
\hline 1 & 57 & Male & $\begin{array}{l}\text { Fluorspar } \\
\text { processor }\end{array}$ & 17 & IgA nephropathy & $\begin{array}{l}\text { Progressive } \\
\text { CRF }\end{array}$ \\
\hline 2 & 60 & Male & Fluorspar miner & 35 & $\begin{array}{l}\text { Microscopic } \\
\text { polyarteritis }\end{array}$ & $\begin{array}{l}\text { Renal } \\
\text { transplant }\end{array}$ \\
\hline 3 & 73 & Male & Ganestar quarrier & 24 & $\begin{array}{l}\text { Small kidneys } \\
\text { on ultrasound }\end{array}$ & $\begin{array}{l}\text { Progressive } \\
\text { CRF }\end{array}$ \\
\hline 4 & 58 & Male & Roadman & 0 & $\begin{array}{l}\text { Post aneurysm } \\
\text { repair }\end{array}$ & Stable CRF \\
\hline 5 & 50 & Male & Fluorspar miner & 11 & $\begin{array}{l}\text { Microscopic } \\
\text { polyarteritis }\end{array}$ & Stable CRF \\
\hline 6 & 61 & Male & $\begin{array}{l}\text { Fluorspar } \\
\text { processor }\end{array}$ & 15 & $\begin{array}{l}\text { Membranous } \\
\text { glomerulonephritis }\end{array}$ & Proteinuria \\
\hline 7 & 76 & Male & Fluorspar miner & 30 & $\begin{array}{l}\text { Microscopic } \\
\text { polyarteritis }\end{array}$ & Haemodialysis \\
\hline 8 & 69 & Female & Housewife & 0 & $\begin{array}{l}\text { Membrano-prolif. } \\
\text { glomerulonephritis }\end{array}$ & Proteinuria \\
\hline 9 & 82 & Female & Housewife & 0 & $\begin{array}{l}\text { End stage } \\
\text { glomerulonephritis }\end{array}$ & Haemodialysis \\
\hline 10 & 30 & Female & Office worker & 0 & $\begin{array}{l}\text { Chronic } \\
\text { pyelonephritis }\end{array}$ & $\begin{array}{l}\text { Renal } \\
\text { transplant }\end{array}$ \\
\hline
\end{tabular}

Patients 1-8 from fluorspar mining area, and 9 and 10 from non-mining area $\mathrm{CRF}=$ chronic renal failure.

Table 2: Occupational silica exposure, and renal diagnosis of identified cases

The excess was not due to inclusion bias, since patients were included only if they were seeing a nephrologist. The separation into mining and non-mining areas was done before searching for renal disease in the database. Since both areas were served by the same family-physician group, the number of cases of renal disease in each area did not differ because of referral patterns.

We suggest that the most probable cause for the excess cases of renal disease was exposure to silica. Silica is increasingly implicated as a cause of renal disease, especially glomerulonephritis. 23 of 45 renal biopsy samples taken at autopsy from people who had died from pulmonary silicosis showed glomerular abnormalities, as well as features of proliferative glomerulonephritis in $23 .{ }^{1}$ A study of glomerular and tubular function in silicotic workers showed severe abnormalities compared with non-exposed matched controls. $^{2}$ A cohort of 2412 silica-exposed gold miners had an increased incidence of end-stage renal failure, particularly secondary to glomerulonephritis. ${ }^{3}$ Silica is associated with glomerulonephritis caused by antibodies to neutrophil cytoplasm (ANCA). ${ }^{4}$ Fluorspar seams are reached through quartz beds and fluorospar workers are highly exposed to silica dust. Until the introduction of wet drilling, the death rate from pulmonary silicosis in fluorspar miners in Upper Weardale was high.

One of the identified patients has mild pulmonary silicosis. If silica exposure does cause renal disease, it must occur at a lower degree of exposure than that leading to pulmonary Silicosis. Although the excess of cases could be a result of other local environmental or genetic factors, the high proportion of silica-exposed male workers suggests an occupational link.

The presence of different types of glomerulonephritis is in keeping with other reports and raises the possibility that histologically distinct types of glomerulonephritis might be precipitated by the same environmental factor. Hydrocarbons are associated with renal disease and are implicated in more than one type of glomerulonephritis. ${ }^{5}$ Our study adds to the evidence that long-term silica exposure may be associated with glomerulonephritis.

We thank W Lumb, A Martin, and the fluorspar workers of Upper Weardale with renal disease for their help.

1 Kolev K, Doitschinov D, Todorov D. Morphological alterations in the kidney by silicosis. Med Lav 1970; 61: 205-10.

$2 \mathrm{Ng}$ TP, Ng YL, Lee HS, et al. A study of silica nephrotoxicity in 